TITLE:

\title{
PARASITIC COPEPODS FROM FISHES OF JAPAN -PART7. CYCLOPOIDA, III AND CALIGOIDA, IV-
}

$\operatorname{AUTHOR}(S):$

Yamaguti, Satyu

\section{CITATION:}

Yamaguti, Satyu. PARASITIC COPEPODS FROM FISHES OF JAPAN -PART7. CYCLOPOIDA, III AND CALIGOIDA, IV-. PUBLICATIONS OF THE SETO MARINE BIOLOGICAL LABORATORY $1953,3(2): 221-231$

ISSUE DATE:

1953-12-20

URL:

http://hdl.handle.net/2433/174466

RIGHT: 


\title{
PARASITIC COPEPODS FROM FISHES OF JAPAN PART 7. CYCLOPOIDA, III AND CALIGOIDA, IV
}

\author{
SATYU YAMAGUTI \\ Zoological Institute, Kyoto University, Kyoto
}

With Plates XIII-XVII (1-5)

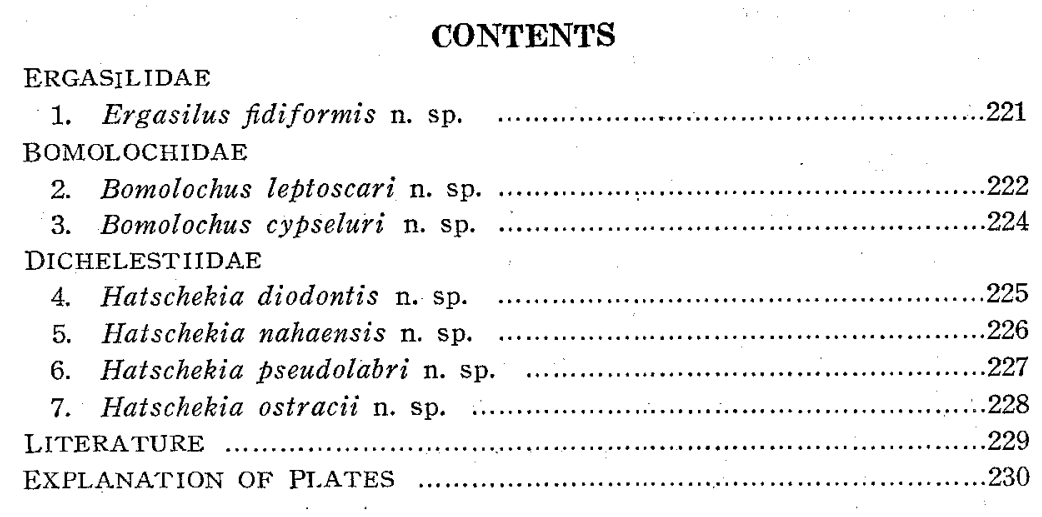

ERGASILIDAE

1. Ergasilus fidiformis n. sp.

(Pl. I. Figs. 1-8)

Habitat. Gills of Sarcocheilichthys variegatus (TEMM. et SCHLFG.), Leuciscus hakonensis GÜNTHER, Pseudorasbora parva (TEMM. et SCHLEG.), Pseudoperilampus typus BLEEKER.

Locality. Tutiura, Ibaragi Prefecture.

Body 0.68-0.85 mm long. Cephalothorax violin-shaped, $0.375-0.45 \times 0.22-0.26 \mathrm{~mm}$, with a distinct constriction on each side at the junction of the head with the first thoracic segment which is just as broad as, or only slightly narrower than, the head; front end truncate conical. Second to fourth thoracic segments short, diminishing in breadth posteriorly with following measurements respectively : 68-85 $\times 150-160 \mu, 55-75$ $\times 110-125 \mu$ and $38-50 \times 65-75 \mu$. Fifth segment flattened, about $10 \mu$ long by $60 \mu$ broad. Genital segment $75-80 \mu$ long by $65-75 \mu$ broad, with maximum breadth near its anterior end. Abdomen $75-100 \times 40-50 \mu, 3$-segmented, pectinated along ventral

Publ. Seto Mar. Biol. Lab., III (2), 1953. (Article 21) 
posterior margin of each segment; segments diminishing in length posteriorly (33 $\mu$, $24 \mu$ and $21 \mu$ in respective length in the type). Caudal rami cylindrical, 33-36 $\times 15-17 \mu$, each with a very long and a shorter, terminal bristle besides two minute setae on posterior ventral margin. Egg tubes $0.25-0.6 \mathrm{~mm}$ long by $0.11-0.15 \mathrm{~mm}$ broad, each containing a few longitudinal rows of eggs.

First antenna 6-segmented, moderately setigerous, tipped with three long setae; three distal segments together only slightly shorter than three proximal segments together $(21: 24 \mu)$. Second antenna a little shorter than cephalothorax, 5 -segmented; first segment short, second curved outward, without bulge, third the longest, fourth and fifth forming together a falcate claw measuring about $130 \mu$ along concave margin as in Pseudergasilus parasiluri Yamaguti, 1936. Mandible 2-segmented; basal segment with a pectinate spiniform process on posterior margin; terminal segment small, pectinated on inner margin and tip. First maxilla with two setae. Second maxilla with shaggy tip. Maxilliped lacking.

Rami of first to fourth legs 3-segmented except fourth exopod which has but two segments. They are armed with spines and setae as follows:

First exopod 1-0, 1-1, 2-5; endopod 0-1, 0-1, 2-4.

Second exopod 1-0, 0-1, 0-6; endopod 0-1, 0-1, 1-4.

Third exopod 1-0, 0-1, 0-6; endopod 0-1,0-1, 1-4.

Fourth exopod 0-1, 1-4; endopod 0-1, 0-1, 1-3.

Fifth leg rudimentary, tipped with two fine setae.

The present species is most closely related to Ergasilus versicolor WiLson, 1911, but differs from it in body size, in the truncate cephalothorax, in the falcate claw of the second antenna being distinctly 2-segmented (1-segmented in WILson's species), in the armature of each thoracic leg, etc.

\section{BOMOLOCHIDAE}

\section{Bomolochus leptoscari n. sp.}

(Pl. I, Figs. 9-11; P1. II, Figs. 12-18)

Habitat. Gills of Leptoscarus japonicus (CUV. et VALENC.).

Locality. Hamazima, Mie Prefecture.

Material. One gravid female.

Body $1.15 \mathrm{~mm}$ long. Cephalothorax hemispherical in dorsal view, $0.41 \times 0.575 \mathrm{~mm}$, with a slightly convex frontal margin projecting beyond base of first antenna. On the midventral side of this frontal plate is a pair of short posterolaterally directed, broad-based spines $21 \mu$ long. Second to fifth thoracic segments free; second and third segments with rounded sides, $0.175 \times 0.6 \mathrm{~mm}$ and $0.15 \times 0.525 \mathrm{~mm}$ respectively; fourth 
segment $0.125 \times 0.275 \mathrm{~mm}$, fifth segment only $60 \mu$ long, with its side produced posterolaterally to form the base for the fifth leg. Genital segment $100 \times 177 \mu$, bulging out laterally immediately in front of the point where the egg sacs are attached. Abdomen tapering posteriorly, consisting of three segments measuring $45 \mu, 30 \mu$ and $42 \mu$ in respective length. Caudal rami $33 \times 25 \mu$, with one seta on dorsolateral margin and four setae at distal end. The longest caudal seta is $0.32 \mathrm{~mm}$ in length. Egg case plump, $0.6 \times 0.225 \mathrm{~mm}$, eggs polygonal, comparatively large.

First antenna projecting slightly beyond lateral margin of cephalothorax; three proximal segments fused, with a transverse row of 14 plumose setae besides 9 simple setae ( 3 ventral, 5 anterior and 1 dorsal), fourth segment with three setae, fifth with three setae, sixth with one marginal and seven terminal setae. Terminal segment of second antenna covered ventrally like a file with several rows of minute comb-teeth extending from its proximal end to tip of blunt-pointed terminal process; a subterminal claw-like seta, a subterminal pectinate process, and five bundled claw-like setae are present as usual. Mandible with simple straight cutting blade. First maxilla with three setae; paragnath forming a blunt-pointed process which is finely pectinated along the posterior and distal anterior margin as well as on the tip. Second maxilla terminating in a bilaterally pectinated blade, with a smaller pectinate palp. Labium with a few transverse rows of minute spiniform teeth. Terminal claw of maxilliped S-shaped, with a curved blunt process on posterior curve. Rami of first to fourth legs 3-segmented,* armed with spines and setae as follows:

First exopod 1-0, 1-0, 2-6; endopod 0-1, 0-1, 0-5.

Second exopod 1-0, 1-0, 3-2; endopod $0-1,0-0,0-3$.

Third exopod 1-0, 1-0, 3-2; endopod 0-1, 0-0, 0-2.

Fourth exopod 1-0, 1-0, 3-0; endopod 0-0, 0-0, 0-2.

Strictly speaking all the "spines" of the exopods are setiform. The fifth leg rod-shaped, $105 \times 48 \mu$, covered with exceedingly small spines at inflated part on anteroventral margin and at distal end of posterior margin, tipped with 2 setae and a short hair.

This species differs from the most closely related Bomolochus decapteri YamaGurt, 1936, in possessing no chitinous hook on the first antenna and no modified maxillary hook behind it, in the structure of the mandible and first maxilla, in the armature of the legs, etc.

* Middle segment of first exopod partly fused with distal segment. 


\section{Bomolochus (Artacolax) cypseluri n. sp.}

(P1. II, Fig. 19 ; P1. III, Figs. 20-27 ; P1. IV, Fig. 28)

Habitat. Gill of Cypselurus agoo (TEMM. et SCHLEG.)

Locality. Hamazima, Mie Prefecture.

Material. A single gravid female.

Body $2.4 \mathrm{~mm}$ long, cephalothorax $0.8 \mathrm{~mm}$ long by $1.25 \mathrm{~mm}$ broad, frontal plate saddle-shaped, dorsal median chitinous rod with a pair of short side branches; lateral margins sloping anteriorly but rounded posteriorly; posterior margin slightly convex. Second thoracic segment $0.725 \mathrm{~mm}$ broad, well rounded at the sides, third $0.58 \mathrm{~mm}$ broad, overlapping the fourth dorsally so as to entirely conceal it, fifth $0.125 \times 0.31 \mathrm{~mm}$.

Genital segment $0.25 \times 0.34 \mathrm{~mm}$, enlarged at the sides where the egg sacs are attached. Abdomen 3-segmented, tapering posteriorly; first segment $0.21 \times 0.24 \mathrm{~mm}$, second $0.15 \times 0.21 \mathrm{~mm}$, third $0.14 \times 0.18 \mathrm{~mm}$. Caudal rami subcylindrical, $0.12 \mathrm{~mm}$ long by $54 \mu$ broad at base, with one seta on outer margin, another on dorsal side near posterior end, still another on inner margin close to two terminal setae, of which the inner is $0.525-0.538 \mathrm{~mm}$ long and the outer $0.14 \mathrm{~mm}$ long. Egg case sausage-shaped, $1.3-1.4 \times 0.26-0.31 \mathrm{~mm}$; eggs polygonal, multiseriate.

First antenna reaching a little beyond lateral margin of cephalothorax. Three proximal segments fused, with a row of 12 plumose setae, of which the distal two are on the ventral side, the others along the anteroventral edge; fourth segment with four setae, fifth with three at distal end, sixth with one subterminal and seven terminal setae, of which one is $0.21 \mathrm{~mm}$ long but the others, especially the dorsal, are minute. Dorsal to the base of the first antenna is a chitinous projection bearing a seta and two spines with delicate tip. Unarmed accessory antennule present, between base of first antenna and anterolateral corner of cephalothorax. Modified maxillary hook as observed in Bomolochus decapteri mihi is also present. Distal segment of second antenna covered ventrally with several irregular rows of spines, produced into a blunt-pointed process with five rows of spines ventrally. Besides this terminal process there are five claw-like terminal setae close together, one seta and one pectinate styliform process subterminally. Mandible with a straight terminal blade $60 \mu$ long and subterminal palp $25 \mu$ long. First maxilla with one simple and three plumose setae; paragnath cheliform, densely haired on anterior, more strongly chitinized ramus. Second maxilla terminating in a pectinate blade, with a narrower pectinate palp. Immediately posteromedial to the base of the second maxilla arises on each side a stout, blunt-pointed, chitinous rod directed posteroventrally and medially. Maxilliped terminating in a S-shaped claw with a plumose seta close to the base.

Exopod of first leg indistinctly 3-segmented; proximal segment bearing a spine 
with a thick rod-shaped base, middle segment compressed, with a slender seta, distal segment with one minute simple seta and six large plumose seta along its rounded margin; endopod 3-segmented, with one plumose setae along its rounded margin; endopod 3-segmented, with one plumose seta for each of proximal and middle segments and 5 for distal segment. Second to fourth legs with 3 -segmented rami, armed with setae and spines which are provided with a minute seta at the tip, as follows :

Second exopod 1-0, 1-1, 3-6; endopod $0-1,0-2,2-3$.

Third exopod 1-0, 1-1, 2-6; endopod $0-1,0-2,2-2$.

Fourth exopod 1-0, 1-1, 2-6; endopod 0-1, 0-1, 2-1.

Fifth leg 2-segmented, proximal segment short, not pectinated, with a seta on dorsal side, distal segment rod-shaped, $0.21-0.22 \times 0.075 \mathrm{~mm}$, with one subterminal and three terminal setae.

This species differs from the most closely related Bomolochus (Artacolax) saetiger WILson, 1911, from the American flying fish in the relative length of the third abdominal segment, the shape of the caudal rami, the smooth cutting blade of the mandible, the structure of the paragnath, the armature of the legs, etc.

\section{DiCHELESTIIDAE}

\section{Hatschekia diodontis n. sp.*}

(Pl. IV, Fig. 29-34)

Habitat. Gills of Diodon holacanthus LINNÉ.

Locality. Naha, Okinawa.

Material. Numerous gravid females.

Body 1.0-1.2 mm long, with large pigment dots scattered dorsally. Head approximately rounded triangular, $0.35-0.41 \times 0.42-0.5 \mathrm{~mm}$, flat in front and rounded behind; dorsal chitinous framework $\mathrm{T}$-shaped, with distinct median sinus in front; median rib simple, fairly long, tapering posteriorly. Trunk elliptical, 0.8-1.0 $\times 0.3-0.475 \mathrm{~mm}$, with maximum breadth in front of its middle. Abdomen nodular, 90-108 $\mu$ in trans: verse diameter. Caudal rami plump, constricted at base, $27-32 \times 15-18 \mu$, with four setae at tip and another on dorsolateral margin. Egg string $0.65-0.96 \mathrm{~mm}$ long, con: taining a series of $8-13$ eggs.

Frontal plate with a blunt-conical process on each side ventral to base of first antenna. First antenna not very distinctly 5-segmented, about $0.25 \mathrm{~mm}$ long, with a row of 14 fragile setae along anteroventral margin, and 12 setae at tip. Second

* This species and the next are included in the Japanese fauna, though the locality where the material: was collected is now outside the Japanese territory. 
antenna 2 -segmented, distal segment comparatively long (135 $\mu$ along concave margin), with a sharp pointed spiniform barb near proximal end and an inconspicuous thickening on concave margin of strongly curved distal portion. Maxilla with two setae on each ramus. Mandible slender, with six very minute teeth. Maxilliped 4-segmented and bifid at tip as usual; second segment as long as third, with a seta at proximal end. There are only two pairs of thoracic legs. No chitinous rods on transverse bar connecting two legs of each pair.

First exopod 2-segmented, twice as long as endopod; proximal segment with one seta at distal corner, distal segment with six setae. First endopod 1-segmented, with four terminal and two subterminal setae. Second exopod 2-segmented; with a large seta at prolonged distal corner, distal segment with five setae. Second endopod 2-segmented; proximal segment with one seta at inner distal end, distal segment with three terminal and two subterminal setae.

This species bears a superficial resemblance to Hatschekia monacanthi YAMAGUTI, 1939, in general body shape, but differs from it in the structure of the dorsal chitinous framework, in the relative length and structure of the two segments of the second antenna, in the exopods of each leg being 2-segmented, etc.

\section{Hatschekia nahaensis n. sp.}

(Pl. IV, Figs. 35-37; Pl. V, Figs. 38 \& 39)

Habitat. Gills of Abudefduf sp.

Locality. Naha, Okinawa.

Material. 2 gravid females.

Body $1.6-1.75 \mathrm{~mm}$ long. Head approximately septangular in dorsal view, $0.3 \times 0.44 \mathrm{~mm}$, with the truncate front bordered by a transverse row of seven tubercles, of which the median corresponds to the dorsal hump of the frontal plate and the other three on each side are nodular swellings of the proximal anterior margin of the first antenna. Neck $0.25 \mathrm{~mm}$ broad. Trunk elliptical, $1.3-1.45 \mathrm{~mm}$ in length, with maximum breadth of $0.55-0.575 \mathrm{~mm}$ just behind its middle with a rounded $(75 \mu$ in diameter) submarginal protuberance projecting outward between the first and the second leg. Abdomen semicircular, with a small ( $35 \mu$ in diameter) rounded midventral protuberance behind anal opening. Caudal rami plump, $20 \times 14 \mu$, with a very minute seta on dorsolateral margin, a longer one on inner margin, and four short ones at tip, the innermost terminal seta swollen at base to a diameter of $12 \mu$. Egg string $1.15-1.5 \times 0.13-0.18 \mathrm{~mm}$, each containing a series of $14-28$ eggs.

First antenna indistinctly 5-segmented; each of the three proximal segments has a hemispherical swelling at the anterior margin and gives the front a beaded appearance. Between the second and the third swelling is a forwardly directed, 
acutely pointed seta; the fourth segment has one seta ventrally, the fifth, however, has 13 setae of varying length and thickness, mostly at the tip and on the ventral side. Second antenna 2-segmented; proximal segment with dotted appearance like a fine file except on the anteroventral side, strongly curved distal segment with similar structure at base except on the papillary swelling on the inner side. Maxilla 2-lobed, each lobe bearing two setae. Mandible slender, with three rudimentary teeth. Maxilliped as in Hatschekia pseudolabri. There are two pairs of legs at the anterior part of the trunk. The endopods of the two legs are one-segmented, though the chitinized outer margin shows an interruption indicating the original segmentation, tipped with two setae. The exopods of the two legs are 2-segmented, the proximal segment with one seta at its outer distal corner, the distal segment of the first leg with two setae, that of the second leg with three setae.

This species is characterized by the peculiar structure of the proximal portion of the first antenna giving the front a beaded appearance, and by the armature of the legs.

\section{Hatschekia pseudolabri n. sp.}

(PI. V, Figs. 40-44)

Habitat. Gills of Pseudolabrus japonicus (HOUTTUYN) and Verreo oxycephalus (BLEEKER). Locality. Komatusima, Tokusima Prefecture.

Material. Several gravid specimens fixed in alcohol and mounted in lactophenolgelatine.

Body elongate, $1.1-1.8 \mathrm{~mm}$ long. Head rounded, $0.25-0.27 \times 0.24-0.3 \mathrm{~mm}$, dorsal chitinous framework consisting of three ribs joining together in front; a median rib bifurcating posteriorly, lateral ribs curved at nearly right angles anteriorly and posteriorly. First thoracic segment forming neck $0.1-0.14 \mathrm{~mm}$ broad, second fused with genital segment into fusiform trunk which is $1.4-1.6 \mathrm{~mm}$ in length with maximum breadth of $0.4-0.55 \mathrm{~mm}$ in front of the middle. The posterior end of the trunk forms a rounded protuberance dorsally. Egg strings $1.2-1.8 \times 0.12-0.13 \mathrm{~mm}$, each containing a series of 20-30 eggs. Abdomen rounded, $40-60 \mu$ in diameter, with a distinct median incision at posterior end. Caudal rami rod-shaped, $20-24 \mu$ long by $9-12 \mu$ broad, attached to ventral side of abdomen, with one small seta on outer margin and four setae at tip.

First antenna indistinctly segmented, measuring about $0.15 \mathrm{~mm}$ long along its posterior margin, with a row of 10 setae along ventral margin and a tuft of setae at tip. Second antenna 2-segmented; terminal claw sharp-pointed. Mandible slender, with four rudimentary teeth. Maxilla 2-lobed, each lobe with 2 setae. Maxilliped 4-segmented, largest second segment with an acutely pointed seta at its proximal end ventrally, third slender, as long as second, fourth bifid at tip. First two pairs of legs biramose; basipod of first leg with a seta at outer end and another just inside 
base of endopod, latter seta lacking on second leg. Rami of each leg 2-segmented, armed with setae as follows :

First exopod 1, $4^{*}$; endopod $0,2$.

Second exopod 1, 2; endopod $0,2$.

Third and fourth legs lacking.

This species differs from the most closely related $H$. labracis (VAN BENEDEN), $H$. leptoscari YAMAGUTI, 1939, atid $H$. branchiostegi YAMAGUTI, 1939, in the chitinous framework on the dorsal side of the head, the armature of the legs, the length of the egg strings and the number of eggs in each string, etc.

\section{Hatschekia ostracii n. sp.}

(Pl. V, Figs. 45-48)

Habitat. Gills of Ostracion tuberculatum LINNÉ.

Locality. Komatusima, Tokusima Prefecture.

Material. Several gravid females.

Body 0.9-1.06 mm long. Head subglobular in dorsal view, $0.35-0.41 \times 0.31-0.36 \mathrm{~mm}$, with a prominent cornuate process projecting outwards between base of second antenna and lateral edge of head. On the dorsal side there are two lateral, hammershaped chitinous frames with an undulating handle and an unpaired $\mathrm{T}$-shaped central frame. The median place of the latter is bifurcate or trifurcate at the tip, and has a pair of slender, posterolaterally directed side branches at about its middle, each anterior lateral arm of the median frame runs along the anterior border of the head and terminates anterolateral to the posterior end of the handle of the paired hammer, it has two inwardly projecting nodular swellings, of which the anterior lies immediately in front of the head of the hammer and the posterior fits into the sinus of the handle of the hammer. There is no neck region between the head and the trunk. The trunk, attached to the head at the base of the maxillipeds, is convex at the sides, $0.3-0.4 \mathrm{~mm}$ in maximum breadth in front of its middle, and has a plump, backwardly directed process like that of Hatschekia hippoglossi (KRÖYER) of SCOTT on each side of its truncate posterior end, where it encloses the base of the genital segment to which the egg strings are attached. Genital segment $90-100 \mu$ in diameter, completely fused with inverted trapezoidal abdomen. Caudal rami rod-shaped, 33-45 $\mu$ by $10-15 \mu$, with 4 setae at tip and another on outer margin. Egg strings $0.38-0.6$ $\times 0.15-0.18 \mathrm{~mm}$, each containing a series of $4-8$ eggs.

First antenna 7-segmented; first basal segment short, with one seta on ventral edge, second segment long, with one seta on anterior margin, two setae on ventral

* Including a very minute one on inner margin. 
edge, other segments comparatively short, seventh with two terminal and nine subterminal setae. Second antenna 3-segmented; basal segment projecting outward in form of a conical protuberance, middle segment somewhat attenuated at middle, with bacillary markings except at proximal anterior corner, measuring $0.18 \mathrm{~mm}$ along concave margin; terminal segment falciform, measuring $90 \mu$ along concave margin. Maxilla with 2 setae on each lobe. Mandible slender, with 4 rudimentary teeth. Maxilliped as usual, third segment a little shorter than second. There are 3 pairs of thoracic appendages. First and second legs with 4 backwardly directed chitinous spines on each transverse bar connecting the basipods. Exopods of first and second legs 2-segmented, proximal segment slightly longer than the distal, with one seta at distal outer corner, distal segment with 4 setae. Endopods of these legs rather indistinctly 2-segmented, basal segment without setae, distal segment with 5 setae for first leg and 4 setae for second leg. Third leg a little behind the broadest part of trunk, reduced to a minute papilliform projection bearing two setae.

This species is unique in possessing a pair of cornuate processes projecting outward beyond the lateral edge of the head at the level of the basal segment of the second antenna which also projects outwards in the form of a conical process.

\section{LITERATURE}

WILSON, C. B. 1911. North American parasitic copepods belonging to the family Ergasilidae. Proc. U. S. Nat. Mus., vol. 39.

YAMAGUTI, S. 1936. Parasitic copepods from fishes of Japan. Part 1. Cyclopoida, I. Published by the author.

YAMAGUTI, S. 1939. Parasitic copepods from fishes of Japan. Part 5. Caligoida, III. Volumen jubilare pro Prof. Sadao Yoshida, vol. II. 


\section{EXPLANATION OF PLATES}

\section{- Plate I}

Figs. 1-8. Female of Ergasilus fidiformis n. sp.

Fig. 1. Dorsal view of mature female.

Fig. 2. First antenna.

Fig. 3. Second antenna.

Fig. 4. Mouth parts.

Fig. 5. First leg.

Fig. 6. Second leg.

Fig. 7. Third leg.

Fig. 8. Fourth leg.

Figs. 9-11. Female of Bomolochus leptoscari n. sp.

Fig. 9. Dorsal view of gravid female.

Fig. 10. Mouth parts.

Fig. 10. Maxilliped.

\section{Plate II}

Figs. 12-18. Female of Bomolochus leptoscari n. sp.

Fig. 12. First antenna.

Fig. 13. Second antenna.

Fig. 14. First leg.

Fig. 15. Second leg.

Fig. 16. Third leg.

Fig. 17. Fourth leg.

Fig. 18. Fifth leg.

Fig. 19. Gravid female of Bomolochus cypseluri, dorsal view.

\section{Plate III}

Figs. 20-27. Female of Bomolochus cypseluri n. sp.

Fig. 20. First antenna.

Fig. 21. Second antenna.

Fig. 22. Mouth parts.

Fig. 23. Maxilliped.

Fig. 24. First leg.

Fig. 25. Second leg.

Fig. 26. Third leg.

Fig. 27. Fifth leg.

\section{Plate IV}

Fig. 28. Fourth leg of female of Bomolochus cypseluri n. sp.

Figs. 29-34. Female of Hatschekia diodontis n. sp.

Fig. 29. Dorsal view of gravid female.

Fig. 30. First antenna

Fig. 31. Second antenna.

Fig. 32. Maxilliped.

Fig. 33. First leg.

Fig. 34. Second leg.

Figs. 35-37. Female of Hatschekia nahaensis n. sp.

Fig. 35. Dorsal view of gravid female.

Fig. 36. Second antenna.

Fig. 37. First leg.

\section{Plate V}

Figs. 38-39. Female of Hatschekia nahaensis n. sp. 
Fig. 38. Maxilliped.

Fig. 39. Second leg.

Figs. 40-44. Female of Hatschekia pseudolabri n. sp.

Fig. 40. Dorsal view of gravid female.

Fig. 41. First antenna.

Fig. 42. Second antenna.

Fig. 43. First leg.

Fig. 44. Second leg.

Figs. 45-48. Female of Hatschekia ostracii n. sp.

Fig. 45. Dorsal view of gravid female.

Fig. 46. Second antenna.

Fig. 47. Second antenna.

Fig. 48. Second leg. 
Vamaguti: Parasitic Copepods from Fishes of Japan VII

Pl. I

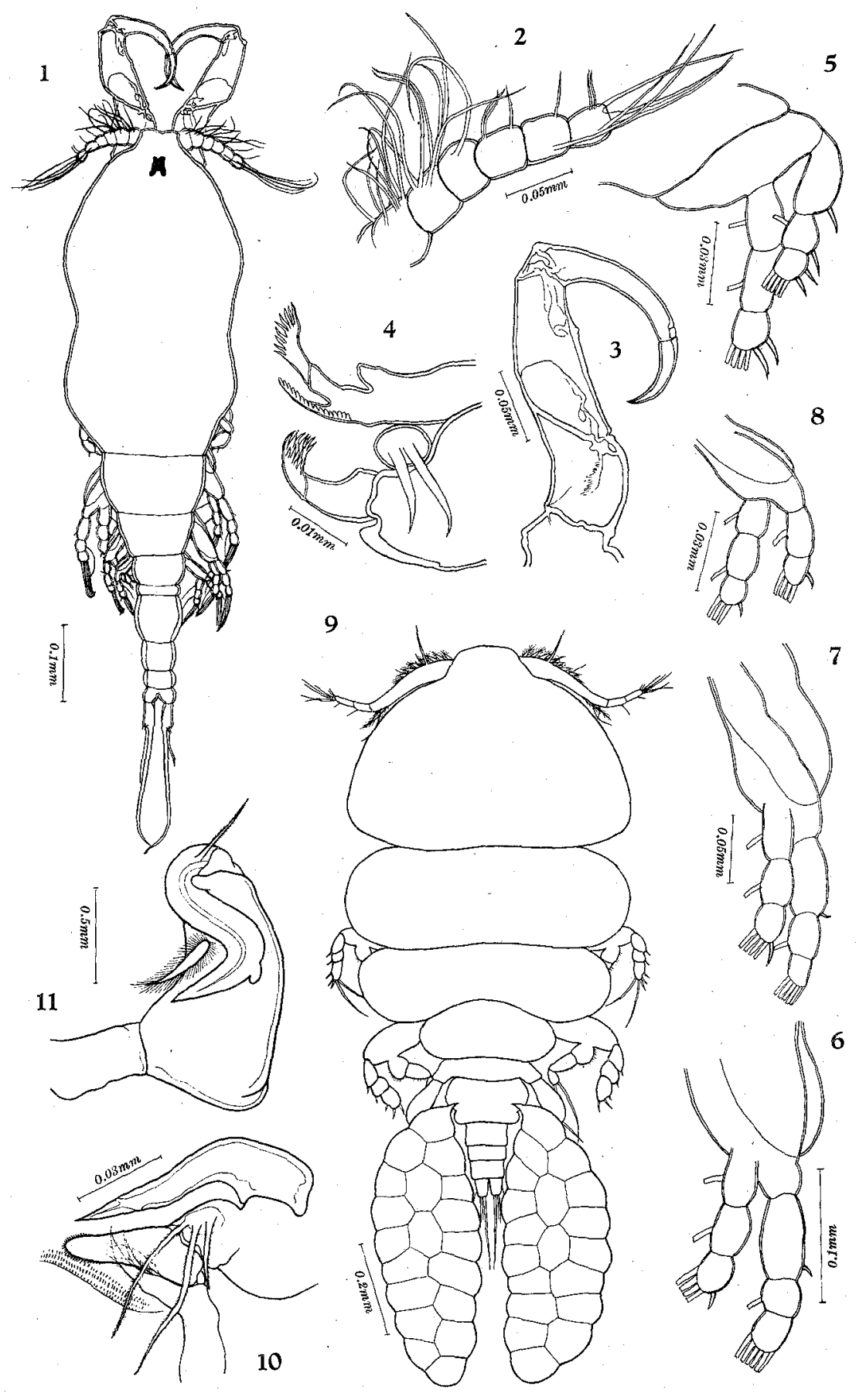


Yamaguti: Parasitic Copepods from Fishes of Japan VII

Pl. I
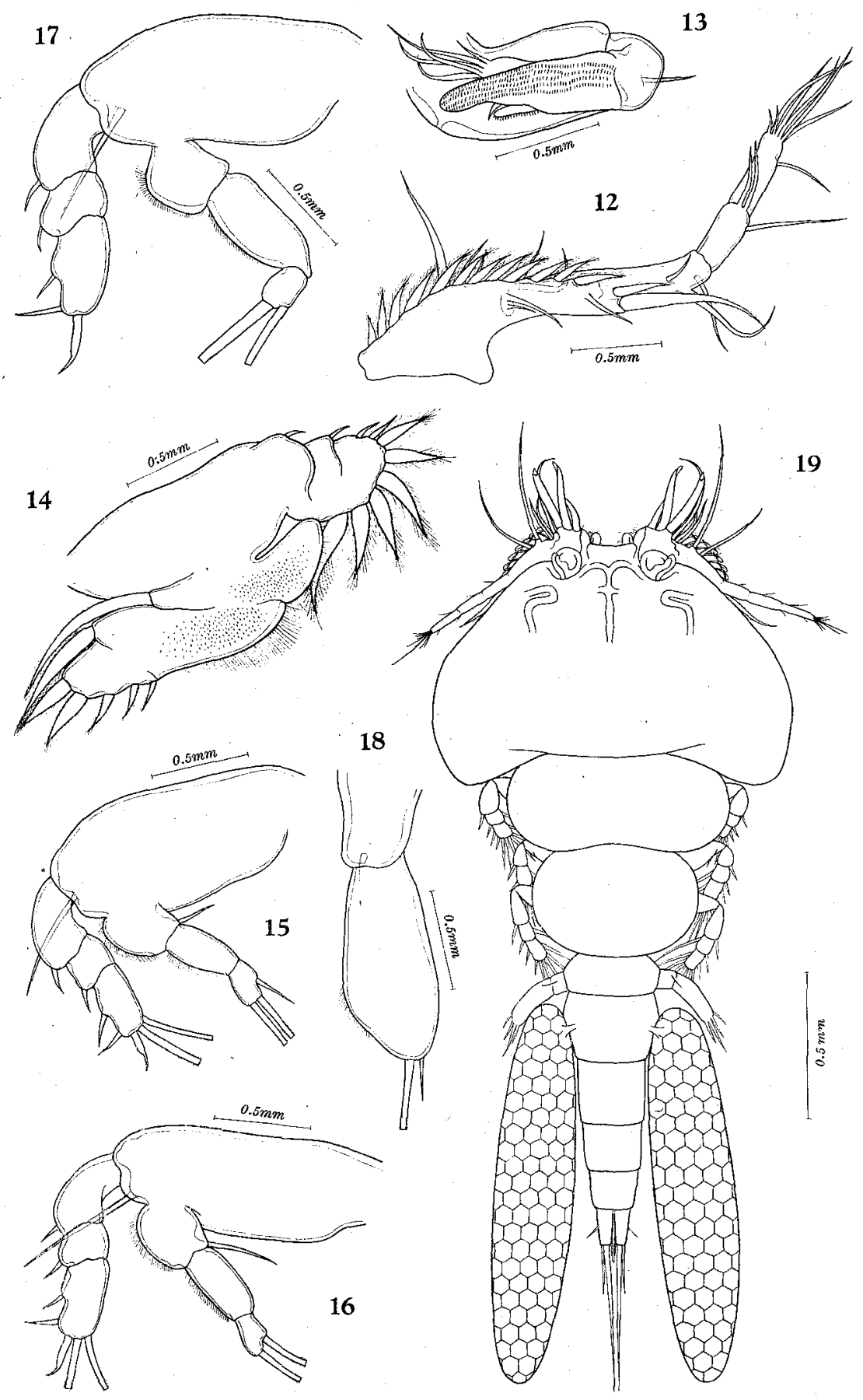
Yamaguti: Parasitic Copfpods from Fishes of Japas VII

Pl. III

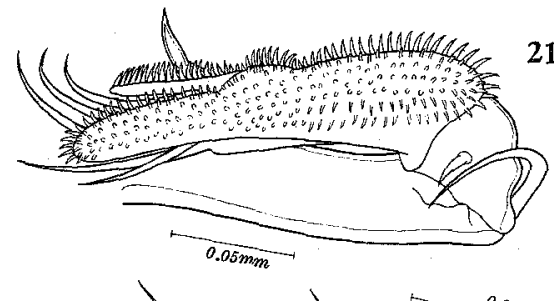

21
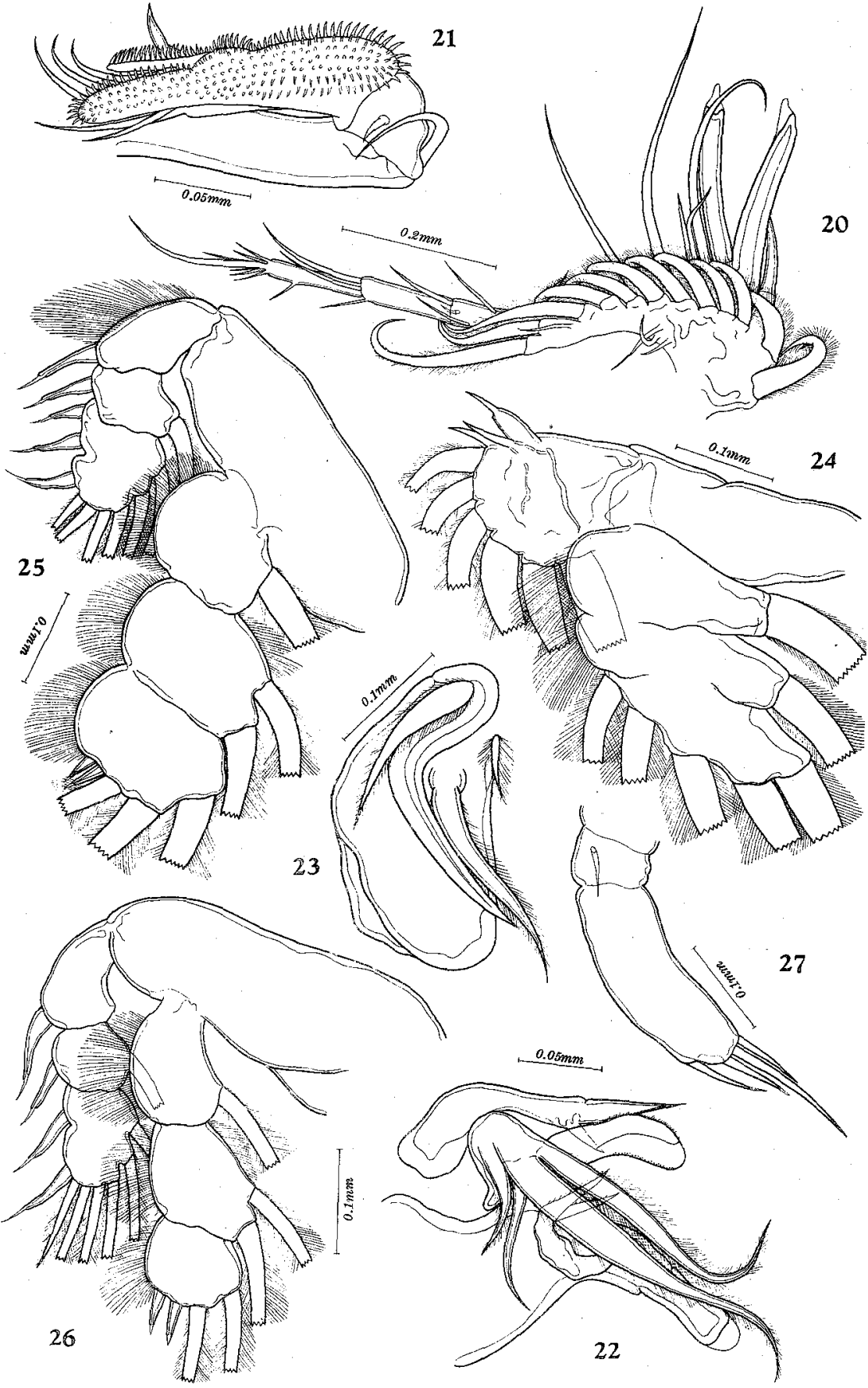
Yamaguti: Parasitic Coperodos from Fishes of Japan VII

Pl. IV

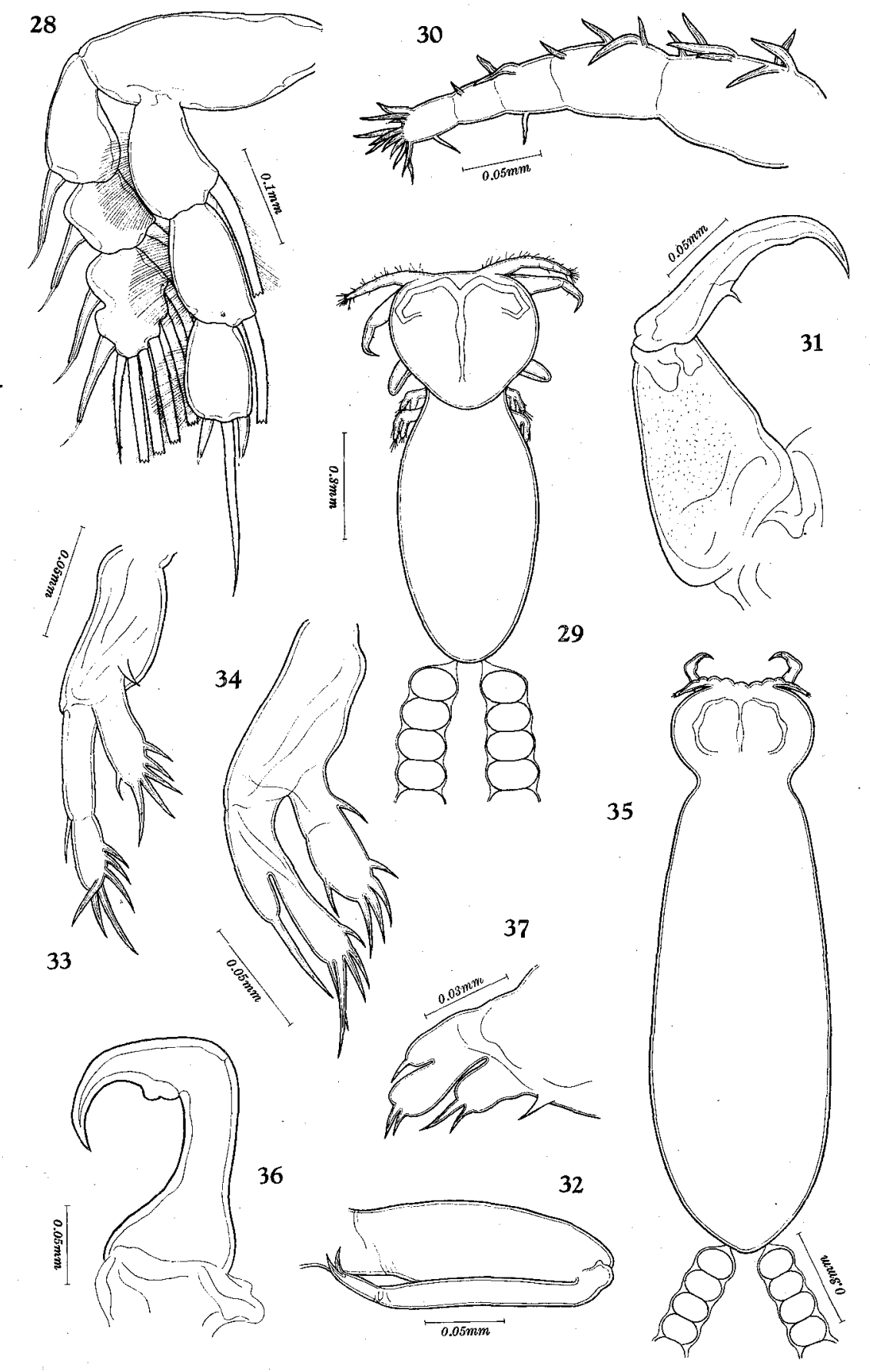


Yamaguti: Parasitic Coperods from Fishes of Japan VII

Pl. V
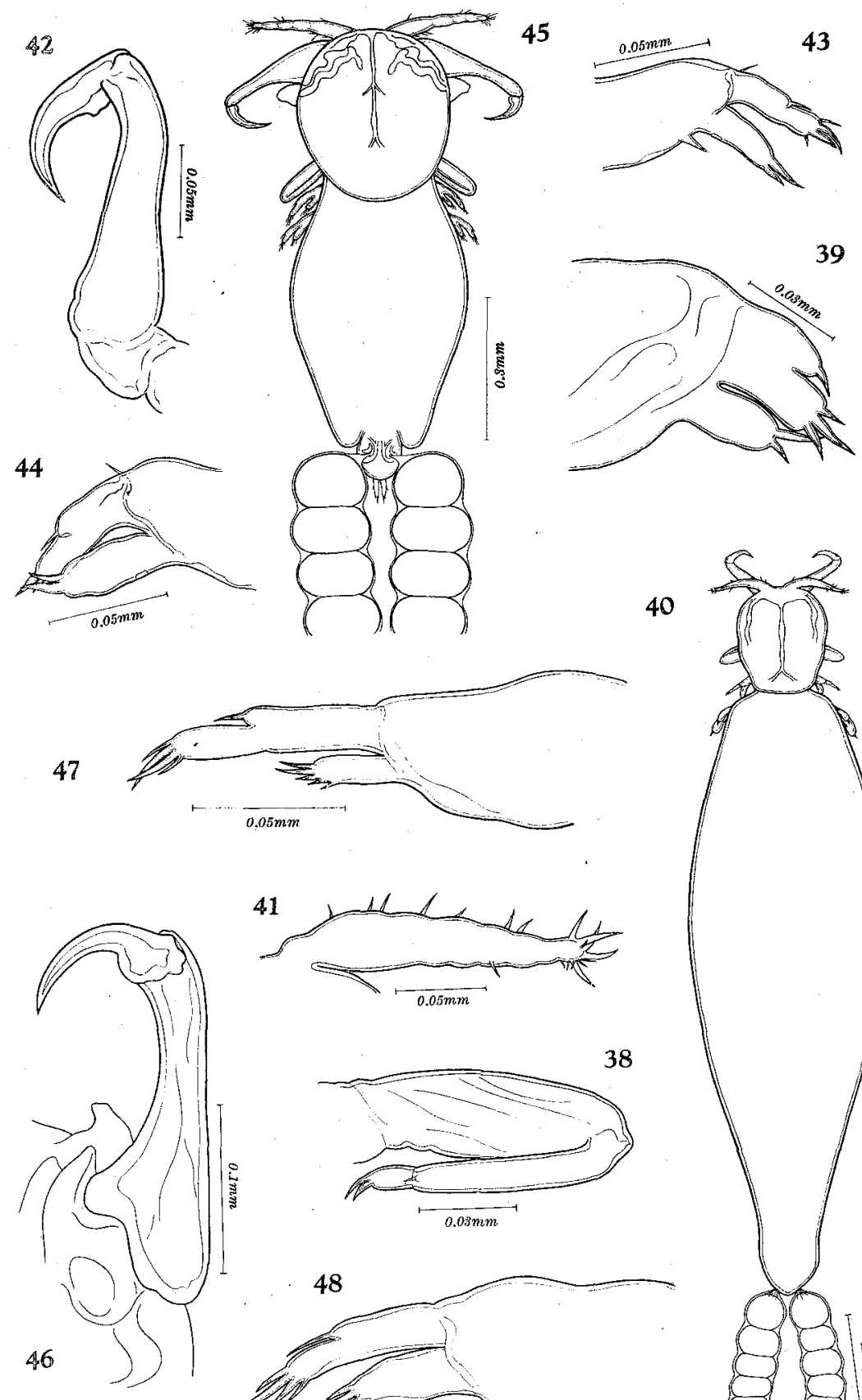

40

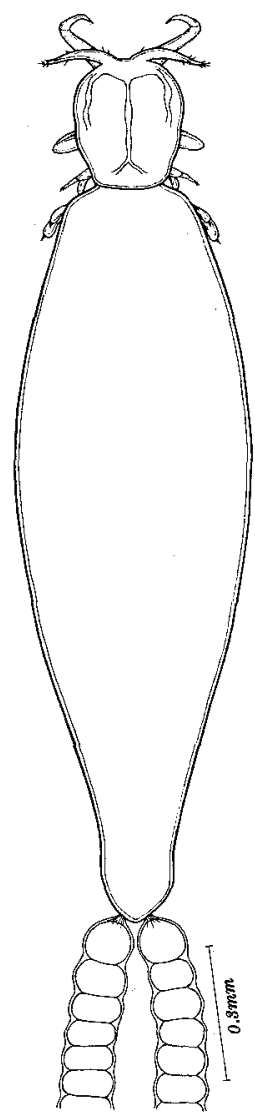

